\title{
Toxicity assessment of arsenic and cobalt in the presence of aquatic humic substances of different molecular sizes
}

\author{
Cláudia Hitomi Watanabe ${ }^{\mathrm{a}}$, Adnivia Santos Costa Monteiro ${ }^{\mathrm{b}}$, Erik Sartori Jeunon Gontijo ${ }^{\mathrm{a}}$, Vivian \\ Silva Lira ${ }^{\mathrm{a}}$, Carolina de Castro Bueno ${ }^{\mathrm{a}}$, Nirmal Tej Kumar ${ }^{\mathrm{a}}$, Renata Fracácio ${ }^{\mathrm{a}}$, André \\ Henrique Rosa ${ }^{a, *}$ \\ ${ }^{a}$ Institute of Science and Technology, Sao Paulo State University (UNESP) - Campus Sorocaba, Av. Três de Março, 511 - Alto da Boa Vista, CEP: 18087-180 Sorocaba, \\ SP, Brazil \\ b Institute of Chemistry, Sao Paulo State University (UNESP) - Campus Araraquara, Av. Professor Francisco Degni, 55 - Jardim Quitandinha, CEP: $14800-060$ \\ Araraquara, SP, Brazil
}

\section{A R T I C L E I N F O}

\section{Keywords:}

Humic substances

Toxicity

Arsenic

Cobalt

C. dubia

Molecular size

\begin{abstract}
A B S T R A C T
The release of contaminants in aquatic ecosystems can be influenced by humic acids. In this study, toxicity tests using environmentally relevant concentrations of arsenic and cobalt were conducted both in the presence and absence of aquatic humic substances (AHS) and the fractions of different molecular sizes in the range of $(<5$, 510;10-30; 30-100 and >100 kDa) using the microcrustacean Ceriodaphnia dubia. AHS together with arsenic reduced the toxicity, and the toxicity decreased in fractions of larger molecular size AHS. Despite the presence of cobalt, the reduction in toxicity was not observed and that depended on the molecular size of AHS. There was a trend of enhanced toxicity for Co in fractions of larger molecular sizes, opposed to that found for arsenic. Thus, the humic substances alter toxicity of trace elements, and this effect varies depending on the size of the humic substances
\end{abstract}

\section{Introduction}

The release of contaminants in water surfaces can modify environmental characteristics and, consequently, change the preexistent aquatic life. This environment is considered a complex system composed of metallic ions, dissolved gases and nutrients such as ammonium, phosphate, nitrate and also organic compounds such as amino acids, humic substances and particulate materials. Some metals with low concentrations (micrograms per liter) are degraded neither by chemical nor by biological reactions (Rocha et al., 2004).

Cobalt is an essential metal that is found in the active site of B12 vitamin and represents an important role in biochemical reactions of life. However, it is also considered toxic in high doses (also cumulatively), and its long-term exposure causes adverse health effects (Siegel, 2002; Simonsen et al., 2012). Therefore, the knowledge related to behavior of this metal is an essential requirement for risk assessment, in order to establish the water quality criteria (Lock et al., 2004; De Schamphelaere et al., 2008). Arsenic is specifically mentioned as a metalloid for having both metallic and nonmetallic characteristics. Even for arsenic, other elements such as arsenic and sulphydric groups of proteins could exert toxic effects by binding to nonmetallic consti- tuents of cellular macromolecules (Walker et al., 2012). Jain and Ali (2000) reported the toxicity of different species of arsenic in the following order: Arsenite $>$ Arsenate $>$ monometilarsenate (MMA) $>$ dimetilarsenite (DMA). In terms of toxicity effect, speciation is considered an essential technique for better understanding of mechanisms of toxicity for chemical elements (Craig, 1986). While chemical analysis identifies and quantifies concentrations of substances, toxicity tests assess the effect of these substances on biological systems. In addition to the above mentioned facts, understanding of the physiological behavior of the bodies assists us in understanding their association with related toxic effects (Costa et al., 2008; Dodds, 2002; Wetzel, 2001). Freshwater invertebrates such as Daphnia magna and Ceriodaphnia dubia are organisms recommended by Environmental Protection Agency (EPA) for toxicity tests in aquatic environments.

The organic matter usually found in aquatic environment influences the reduction of toxicity levels via naturally available elements such as metal ions of organisms present in these environments (Al-Reasi et al., 2011). Formed from the biological and enzymatic decomposition of plant and animal residues, humic substances (HS) are considered the main component of natural organic matter (NOM), globally present in the terrestrial and aquatic environments (Stevenson, 1994). The

\footnotetext{
* Corresponding author.

E-mail address: ahrosa@sorocaba.unesp.br (A.H. Rosa).
} 
molecular fractionation is a procedure that helps to understand better the complex matrices of the organic matter present in the aquatic environments, which in turn has proven to be one of the most important techniques for studying the behavior of these substances in water (Sargentini Jr. et al., 2001). Limited knowledge about the influence of the fractionally dissolved organic carbon (DOC) in complex solutions, become a factor of concern due to the potential of contamination represented by the pollutants in an aquatic environment (Markich et al., 2002).

The study of humic substances based on molecular size could be considered, in principle, as a simple method to study the nature of complex mixtures of macromolecules by their molecular sizes, thus facilitating the study of the properties of HS (Swift, 1989). This study may be accomplished by using the tangential flow ultra-filtration technique with membrane filters (Burba et al., 1998; Rocha et al., 2000). The methodology focused on the use of fractionation of humic substances using an ultra-filtration system to separate and concentrate the humic substances extracted from both water and soil samples (also useful and suitable to work with samples of high volumes). Ultrafiltration has been established as an efficient and reliable technique for the evaluation of metal-HS stability function (Nifant'eva et al., 1999). In this context, the present study aimed to evaluate the influences of different molecular sizes of Aquatic Humic Substances (AHS) with As e Co, by using Ceriodaphnia dubia as part of ecotoxicological tests.

\section{Materials and methods}

For assessment of arsenic and cobalt interactions with AHS the following procedural steps are depicted in Fig. 1.

\subsection{Water collection and AHS extraction}

Water used in this experiment was collected from Sorocabinha River which is situated in Iguape city, Brazil (Latitude: $24^{\circ} 41^{\prime} 59^{\prime \prime} \mathrm{S}$, Longitude: $47^{\circ} 33^{\prime} 05^{\prime \prime} \mathrm{W}$ ). This region is famous for having high concentration of natural organic matter. Chromatographic method following literature recommendation (International Humic Substances

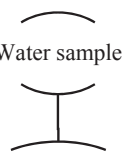

Humic substances extraction

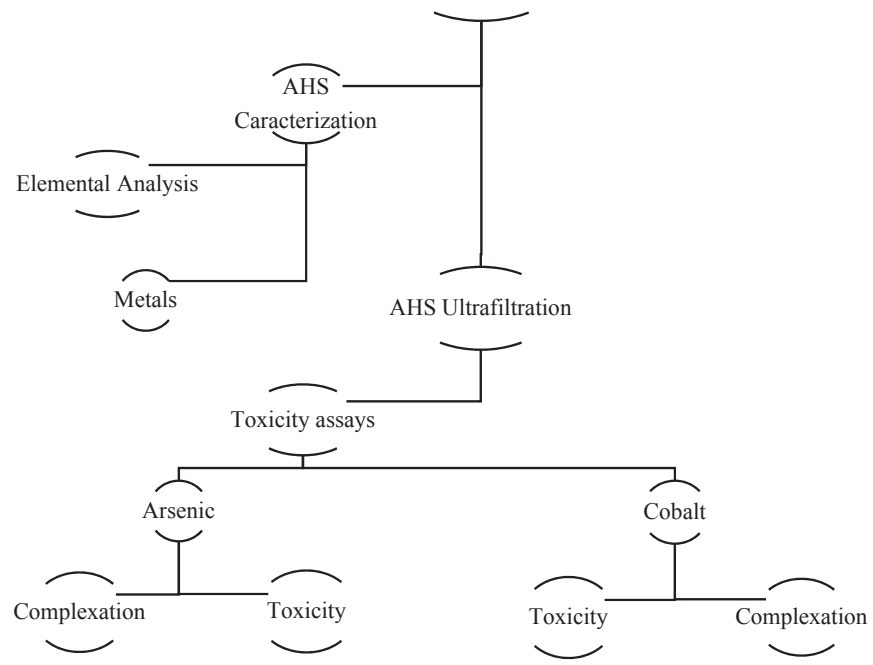

Fig. 1. Diagram of the steps for ecotoxicology assesment of arsenic and cobalt using $C$. dubia at this work.
Society, IHSS; Thurman and Malcolm, 1981) using column packed resin Superlite $^{\mathrm{TM}}$ DAX-8 (Sigma Aldrich) was employed in extraction procedure. The water collected in Sorocabinha River was acidified to a $\mathrm{pH}$ value of 2 and the humic substances were retained in the resin when the water passed through the XAD-8 column in a slow stream. The AHS adsorbed was eluted with Sodium Hydroxide (P.A. Dinâmica) at $0.1 \mathrm{~mol} \mathrm{~L}^{-1}$. The humic substances extracts were acidified to obtain a $\mathrm{pH}$ value of 6.2 using $\mathrm{HCl}$ (P.A. Synth) solution at $0.1 \mathrm{~mol} \mathrm{~L}^{-1}$ and stocked. The $\mathrm{pH}$ value was adjusted according to in situ measurement.

\subsection{Molecular fractionation using ultra-filtration process}

With use of a sequential UF through a series of appropriate membranes, it was possible to characterize the distribution of HS and its metal species as a function of molecular size (Burba et al., 1998). The extracted AHS based on procedures described in item 2.1 was subjected to a sequence of molecular fractionation, comprising an ultra-filtration system (UF System) with specific sizes of regenerated cellulose membrane (Millipore of $76 \mathrm{~mm}$ diameter) and UF cell, adapted from the experimental description (Burba et al., 1998; Rocha et al., 2000). The system was connected to Tygon ${ }^{\circledR}$ brand tubes with flow controllers using a peristaltic pump. Initially, the system was cleansed with ultrapure water, $\mathrm{HCl}$ solution at $0.001 \mathrm{~mol} \mathrm{~L}^{-1}$ and $\mathrm{NaOH}$ solution at $0.1 \mathrm{~mol} \mathrm{~L}^{-1}$. Towards the end of the procedure as described before, the residue was withdrawn for further cleansing to achieve an earlier ultra-filtration level before initializing the fractionation. Then, $250 \mathrm{~mL}$ of AHS extract, $1.6 \mathrm{~g} \mathrm{~L}^{-1}$ TOC was primarily subjected to ultrafiltration process using a membrane of $100 \mathrm{kDa}$ porosity. After complete ultra-filtration (about $12 \mathrm{~h}$ ), the UF cell was carefully opened, the retained material was collected using ultra-pure water and measured by means of a volumetric flask of $25 \mathrm{~mL}$, for subsequent quantification of the carbon content present in the fraction. The same procedure was sequentially repeated using different membranes with porosity values of 30,10 and $5 \mathrm{kDa}$ respectively to enable filtering the contents of the material under consideration in the descending order, related to the size of the aforementioned pore membranes. At the end of the 4th sequential step of ultrafiltration, 5 fractions of different molecular sizes were obtained: > $100 \mathrm{kDa}$, between 30 and $100 \mathrm{kDa}$, between 10 and $30 \mathrm{kDa}$, between 5 and $10 \mathrm{kDa}$, and lower than $5 \mathrm{kDa}$ : F1, F2, F3, F4 and F5, respectively. The dissolved organic carbon (DOC) was determined at high temperature $\left(850^{\circ} \mathrm{C}\right)$ oxidation using carbon analyzer (AnalytikJena multi N/C 3100). Potassium hydrogen phthalate (P.A., Synth) was used to determine organic carbon while sodium carbonate (P.A., Qhemis) and sodium hydrogen carbonate (P.A. Synth) were used to determine inorganic carbon.

\subsection{AHS characterization}

For elemental analysis, $50 \mathrm{~mL}$ of AHS was dried using lyophilization process, a low heat method that obtains solid sample, as described in Aiken (1985 apud Rocha and Rosa, 2003). Part of dried sample was conducted by an elemental analyzer (CE Instruments), thus obtaining percentual of carbon (C), hydrogen (H), nitrogen (N) and sulfur (S). An acid digestion was performed on AHS in order to determine the concentration of metals. Therefore, based on the method 3050b by US Environmental Protection Agency (US EPA, 1996), AHS was dried at a temperature of $35{ }^{\circ} \mathrm{C}$ and $0.1 \mathrm{~g}$ of humic material was weighed in triplicate. Using a sub-boiling system, the acids used in digestion process were previously purified by distillation process. Concentrated hydrochloric and nitric acids and concentrated hydrogen peroxide were added at temperature of up to $100{ }^{\circ} \mathrm{C}$ using the heating support plate. Subsequently after completing digestion, each sample was measured using a volumetric flask and quantified using ICP-OES, 720 series Model, Agilent equipment. The instrument parameters used in this experimental work were $1.1 \mathrm{~kW}$ (power), $15.0 \mathrm{~L} \mathrm{~min}^{-1}$ (plasma flow), $1.5 \mathrm{~L} \mathrm{~min}^{-1}$ (auxiliary flow), $0.75 \mathrm{~L} \mathrm{~min}^{-1}$ (nebulizer flow), $1.0 \mathrm{~s}$ 
(replicate read time), $15 \mathrm{~s}$ (instrument stabilization delay) and for sample introduction settings: $15.0 \mathrm{~s}$ (sample uptake delay) and $15 \mathrm{~s}$ (rinse time).

\subsection{Test solution}

The stock solution of cobalt $\left(1 \mathrm{~g} \mathrm{~L}^{-1}\right)$ was prepared using $65 \mathrm{~g}$ of cobalt chloride hexahydrate salt $\mathrm{CoCl}_{2} \cdot 6 \mathrm{H}_{2} \mathrm{O}$ (P.A., Synth) dissolved in $100 \mathrm{~mL}$ of water containing $25 \mathrm{~mL}$ of concentrated hydrochloric acid. To prepare $1 \mathrm{~L}$ of stock arsenic III (As) solution $\left(1 \mathrm{~g} \mathrm{~L}^{-1}\right), 1 \mathrm{~g}$ of arsenic acid (P.A. Dinamica) in $25 \mathrm{~mL}$ of $\mathrm{NaOH}(20 \%)$ was neutralized with diluted $\mathrm{H}_{2} \mathrm{SO}_{4}$ (P.A., Synth) and then the rest of the solution was filled up with $\mathrm{H}_{2} \mathrm{SO}_{4} 1 \%(\mathrm{v} / \mathrm{v})$. Methodological validation for arsenic was done by using an analytical technique of graphite furnace atomic absorption spectrometry (GFAAS), Varian, AA240FS Model (Gontijo et al., 2016). The detection limit (LOD) values and quantization limit (LOQ) for arsenic was 1.43 and $4.76 \mu \mathrm{g} \mathrm{L}^{-1}$, respectively. For cobalt, using the Spectrometry Optical Emission by Inductively Coupled Plasma (ICP-OES, Agilent, 720 series Model), the LOD and LOQ values for cobalt element were, 4.56 and $15.21 \mu \mathrm{g} \mathrm{L}{ }^{-1}$, respectively. To assess the toxicity of theses elements considering environmental conditions, metal concentration used for Arsenic (10 and $\left.20 \mu \mathrm{g} \mathrm{L}^{-1}\right)$ and Cobalt (50 and $100 \mu \mathrm{g} \mathrm{L}^{-1}$ ) were based on limits established by country legislation related to freshwaters (Brasil, 2005).

\subsection{Ceriodaphnia dubia cultures}

Methodological procedures of maintenance recommended by US Environmental Protection Agency (US EPA, 2002) and Brazilian Association Standard Techniques (ABNT, 2010) were used to C. dubia cultive. Massive cultures of these microorganisms were maintained in soft water renewed two times per week, with specific light and temperature, fed daily and carrying out sensitivity tests to guarantee the assay reproducibility. Table 1 exposes an overview of general conditions used to cultivate and maintain Ceriodaphnia dubia assays.

\subsection{Bioassay}

Five distinct experiments were performed to attest the effect of molecular size using reproduction and mortality data obtained with the ecotoxicological assays. The following conditions were tested: absence of As and Co; as $10 \mu \mathrm{g} \mathrm{L}^{-1}$; Co $50 \mu \mathrm{g} \mathrm{L}^{-1}$ (environmental concentration); as $20 \mu \mathrm{g} \mathrm{L}^{-1}$ and Cobalt $100 \mu \mathrm{g} \mathrm{L}^{-1}$ (high concentration, factor 2 related to environmental concentration). For each condition, the molecular size of organic matter was variated, obtaining 5 treatments per experiment (F1, F2, F3, F4, F5), each one with 10 replicates.

Table 1

Cultive conditions for C. dubia adapted from US EPA (2002) and ABNT (2010).

\begin{tabular}{ll}
\hline Parameter & Cultive condition \\
\hline $\mathrm{pH}$ & $6,8-8,0$ \\
Cultive water hardness ${ }^{\mathrm{a}}$ & $40 \mathrm{a} 48 \mathrm{mg} \mathrm{CaCO} \mathrm{L}^{-1}$ \\
Temperature & $23-27^{\circ} \mathrm{C}$ \\
Photoperiod & $16 \mathrm{~h} \mathrm{light}-8 \mathrm{~h}$ dark \\
Food & Algal solution (Pseudokirchneriella subcapitata): 1- \\
& $5 \times 10^{5}$ cells to organism diary. \\
& Complementary food ${ }^{\mathrm{b}}-0,02 \mathrm{~mL}$ for organism (each \\
& renewal). \\
Number of organism for & 50 \\
$\quad$ aquarium & 2 \\
Weekly renewal of cultive & \\
$\quad$ water &
\end{tabular}

${ }^{a}$ Hardness adjusted using following salts: Calcium sulfate dihydrate, Sodium bicarbonate, Magnesium sulfate heptahydrated and Potassium nitrate.

${ }^{\mathrm{b}}$ Solution of digested fish feed and filtered yeast.
Furthermore, to evaluate the presence of metals, a control treatment without organic matter (CTRL) was considered to attest the hypothetical effect of metal/metalloid concentration over reproduction and mortality. Altogether, 34 experimental conditions were evaluated with ten replicates per condition $(\mathrm{N}=340)$. The bioassay was performed by adding, when necessary, dopant and/or organic carbon in concentration of $10 \mathrm{mg} \mathrm{L}^{-1}$ in terms of TOC (representing $20 \mathrm{mg} \mathrm{L}^{-1}$ of AHS in freshwater (Suffet and Macarthy, 1989)) using reconstituted water. The semi-static assays were maintained in conditions already described (Table 1) for 7-8 days, renewing water 2 times during the test. Physicochemical parameters electrical conductivity, hardness, $\mathrm{pH}$ and dissolved oxygen were monitored. For biological parameters, mortality and reproduction were assessed. The latter was measured based on the number of neonates produced by parthenogenesis.

\subsection{Statistical analyses}

For statistical analyses, single factor Analyses of Variance (ANOVAs) was performed to attest the response of reproduction to molecular size and metal concentration in comparison to control. Once six treatments were considered for molecular size (CTRL, 0-5; 5-10; 10-30; 30-100 and $>100 \mathrm{kDa}$ ), a post hoc Tukey's test was also performed to get pairwise comparisons (Logan, 2010). Mortality provided binary data. To test its response to molecular size and to metal concentration in comparison to the control, Analyses of Deviance based on Chi-squared considering logistic distribution was performed. Confidence intervals of 95\% was considered in the analyses (Logan, 2010). The statistical analyses were performed by using RStudio software and R environment (R Core Team, 2016).

\subsection{Complexation experiments}

The solutions produced during the bioassays (item 2.6) were ultrafiltrated to determine the contents of free metals (FM) and subtracting total metal concentration (TM), the rate of metal-AHS complexes was obtained. To acquire this values, $100 \mathrm{~mL}$ of each test solution was stored in a vial previously decontaminated. In order to determine the real concentration of the experiment (TM), an aliquot of $10 \mathrm{~mL}$ was collected and acidified with $\mathrm{HNO}_{3} 20 \%$ (v/v). The remaining part was ultra-filtered using the UF system and $1 \mathrm{kDa}$ membranes (Millipore). The metal concentration was quantified using GFAAS and ICP-OES, for arsenic and cobalt, respectively.

\section{Results and discussion}

\subsection{Characterization results}

The results of elemental analysis of $\mathrm{C}, \mathrm{H}, \mathrm{N}, \mathrm{O}$ and $\mathrm{S}$ for AHS are disposed in Table 2. The most parto of AHS is formed by carbon (44.51\%) and oxygen (50.92\%). Data close enough to those could be found in the published literature. Both of the AHS samples collected during different designated times in the past two years in the same region, were compared with the AHS samples collected from Itapanhaú region in Brazil. Comparison between humic substances collected in two different years at different places, showed that the elemental analyses were similar in both cases. The elemental composition of organic compounds was used to indicate the degree of aromaticity and decomposition of the organic material (Rosa et al., 2005). Higher values of atomic ratio $\mathrm{C} / \mathrm{N}$ are associated with the degrees of humification (Stevenson, 1994; Araújo et al., 2002). Araújo et al. (2002) also determined the elemental composition of humic fractions in the Iguape/Sao Paulo region in Brazil. The $\mathrm{H} / \mathrm{C}$ ratio indicated high aromaticity and F1 and F5 were most aromatic fractions. The $\mathrm{C} / \mathrm{N}$ ratio was similar in nature for fractions related to the degree of humification. However, the portion indicating that F5 had lower degree of humification in relation to the other could be associated with the 
Table 2

Data of elemental analysis, concentration values metal and C/H, C/N, C/O, H/O atomic ratios of AHS sample extra of Sorocabinha River comparing with literature.

\begin{tabular}{|c|c|c|c|c|c|c|}
\hline Analysis & AHS extract & $\mathrm{F} 1$ & $\mathrm{~F} 2$ & F3 & F4 & F5 \\
\hline DOC Percentage (\%) & - & 2.3 & 3.71 & 6.51 & 16.92 & 69.93 \\
\hline C $(\%)$ & 44.51 & $37.85^{*}$ & $37.15^{*}$ & $36.27^{*}$ & $33.17^{*}$ & $7.06^{*}$ \\
\hline H (\%) & 4.51 & $1.44^{*}$ & $3.93 *$ & $3.9^{*}$ & $3.59^{*}$ & $0.59^{*}$ \\
\hline N (\%) & $<\mathrm{LD}$ & $0.61 *$ & $1.3^{*}$ & $1.51^{*}$ & $1.54^{*}$ & $3.33^{*}$ \\
\hline $\mathrm{O}(\%)$ & 50.92 & - & - & - & - & - \\
\hline S (\%) & 0.05 & - & - & - & - & - \\
\hline $\mathrm{H} / \mathrm{C}$ & 1.22 & $0.46^{*}$ & $1.27 *$ & $1.29^{*}$ & $1.3^{*}$ & $1.00^{*}$ \\
\hline $\mathrm{C} / \mathrm{N}$ & - & $30.67^{*}$ & $33.34 *$ & $28.02 *$ & $25.13^{*}$ & $1.47^{*}$ \\
\hline $\mathrm{C} / \mathrm{O}$ & 1.17 & - & - & - & - & - \\
\hline $\mathrm{H} / \mathrm{O}$ & 0.02 & - & - & - & - & - \\
\hline $\mathrm{Al}\left(\mathrm{mg} \mathrm{kg}^{-1}\right)$ & 2223.36 & - & - & - & - & - \\
\hline As $\left(\mathrm{mg} \mathrm{kg}^{-1}\right)$ & 1.45 & - & - & - & - & - \\
\hline $\mathrm{Ca}\left(\mathrm{mg} \mathrm{kg}^{-1}\right)$ & 120.47 & - & - & - & - & - \\
\hline $\mathrm{Cd}\left(\mathrm{mg} \mathrm{kg}^{-1}\right)$ & $<\mathrm{LD}$ & - & - & - & - & - \\
\hline $\mathrm{Co}\left(\mathrm{mg} \mathrm{kg}^{-1}\right)$ & $<\mathrm{LD}$ & - & - & - & - & - \\
\hline $\mathrm{Cr}\left(\mathrm{mg} \mathrm{kg}^{-1}\right)$ & $<\mathrm{LD}$ & - & - & - & - & - \\
\hline $\mathrm{Cu}\left(\mathrm{mg} \mathrm{kg}^{-1}\right)$ & 3.98 & - & - & - & - & - \\
\hline $\mathrm{Fe}\left(\mathrm{mg} \mathrm{kg}^{-1}\right)$ & 3272.95 & - & - & - & - & - \\
\hline $\mathrm{Mg}\left(\mathrm{mg} \mathrm{kg}^{-1}\right)$ & 182.16 & - & - & - & - & - \\
\hline $\mathrm{Mn}\left(\mathrm{mg} \mathrm{kg}^{-1}\right)$ & 8.80 & - & - & - & - & - \\
\hline $\mathrm{Ni}\left(\mathrm{mg} \mathrm{kg}^{-1}\right)$ & $<\mathrm{LD}$ & - & - & - & - & - \\
\hline $\mathrm{Pb}\left(\mathrm{mg} \mathrm{kg}^{-1}\right)$ & 1.53 & - & - & - & - & - \\
\hline $\mathrm{Sr}\left(\mathrm{mg} \mathrm{kg}^{-1}\right)$ & $<\mathrm{LD}$ & - & - & - & - & - \\
\hline $\mathrm{Zn}\left(\mathrm{mg} \mathrm{kg}^{-1}\right)$ & $<\mathrm{LD}$ & - & - & - & - & - \\
\hline
\end{tabular}

$<\mathrm{LD}=$ Lower than detection limit; * Data obtained from Araújo et al. (2002); (-)=not measure data; F1-F5 = molecular sizes ranges: <5, 5-10; 10-30; 30-100 and > $100 \mathrm{kDa}, \mathrm{F} 1, \mathrm{~F} 2, \mathrm{~F} 3, \mathrm{~F} 4$ e F5, respectively.

presence of less humified compounds such as amino-acids and proteins. The percentage of DOC in each molecular fraction obtained after fractionation are shown in Table 2. It is possible to observe that the portion of DOC under $5 \mathrm{kDa}$, represents is 20 times larger than the largest molecular size portion and it is also four times higher when compared to the second fraction containing a higher percentage of organic carbon. Studies in literature showed that major fractions of the investigated HS from various aquatic systems were below $10 \mathrm{kDa}$ and that a considerable part was under $1 \mathrm{kDa}$. Apparently this can be attributed to the class of fulvic acids (Burba et al., 1998). Sargentini Jr. et al. (2001) observed that the main portion of AHS was smaller than $5 \mathrm{kDa}$ and four times greater than the highest molecular size fraction (greater than $100 \mathrm{kDa}$ ). Araújo et al. (2002) studied and investigated a method for distributing dissolved organic carbon in the same region, but in different areas. The results showed lower values for low DOC fraction (F5) and higher concentrations in the highest fraction. Santos et al. (2011) also studied the distribution of fractions in which the fraction of $100 \mathrm{kDa}$ had a higher portion compared with other fractions. Our current research justifies this behavior after performing the experiments with the samples using different extraction processes of AHS. The results are compatible to those published in scientific literature which show that variable humic substances do occur in nature.

For AHS metal contents, higher concentrations of aluminum, calcium, iron and magnesium were detected and potentially toxic trace metals like arsenic, copper, manganese and lead are shown in Table 2. By comparing the metals present in the surface water using an extracted HS method, we observed that, in the current scenario, material concentration and composition are related with each other. Moruzzi and Reali (2012) noted the presence of higher concentrations of iron and manganese associated with organic matter. $\mathrm{Al}$ and Fe concentrations in natural water of the same river were observed in literature (Oliveira et al., 2014). The authors suggested that the concentration of these elements are associated to geological process being part of an Environmental Protection Area of Sao Paulo State, Brazil. Thus, we observed that the presence of metals in superficial water was directly
Table 3

Results of ANOVA analyses for reproduction and deviation analyses to mortality for size molecular and metal effects. As $10=10 \mu \mathrm{gL}^{-1}$ absence of AHS $\times$ presence of AHS; As $20=20 \mu \mathrm{gL}^{-1}$ absence of AHS $\times$ presence of AHS; Co $50=50 \mu \mathrm{gL}^{-1}$ absence of AHS $\times$ presence of AHS; Co $100=100 \mu \mathrm{gL}^{-1}$ absence of AHS $\times$ presence of AHS.

\begin{tabular}{|c|c|c|c|c|c|c|c|c|}
\hline \multirow[t]{3}{*}{ Test } & \multicolumn{4}{|c|}{ Molecular size effect } & \multicolumn{4}{|c|}{ Metal effect } \\
\hline & \multicolumn{2}{|c|}{ Reproduction } & \multicolumn{2}{|l|}{ Mortality } & \multicolumn{2}{|c|}{ Reproduction } & \multicolumn{2}{|l|}{ Mortality } \\
\hline & $\mathrm{p}$ value & $\mathrm{n}$ & $\mathrm{p}$ value & $\mathrm{n}$ & $\mathrm{p}$ value & $\mathrm{n}$ & $\mathrm{p}$ value & $\mathrm{n}$ \\
\hline As 10 & $<0.001$ & 60 & 0.598 & 60 & 0.752 & 20 & 1 & 20 \\
\hline As 20 & $<0.001$ & 60 & 0.198 & 60 & $<0.001$ & 20 & 1 & 20 \\
\hline Co 50 & $<0.001$ & 60 & $<0.001$ & 60 & $<0.001$ & 20 & 0.084 & 20 \\
\hline Co 100 & $<0.001$ & 60 & $<0.001$ & 60 & $<0.001$ & 20 & $<0.001$ & 20 \\
\hline Size & 0.339 & 60 & 0.559 & 50 & - & - & - & - \\
\hline
\end{tabular}

related to the presence of metals found in AHS samples that were taken from the same location. Due to presence of these elements in the HS samples studied, it is important to consider the issue of toxicity of AHS matrix for the ecotoxicological studies, due to the influence or interaction of these components with the bodies used in these tests.

\subsection{Biossay}

\subsubsection{Metal effect}

Supplementary material (S1) showed the physicochemical parameters obtained after toxicity assays. No considerable variability was observed when comparing the initial physicochemical condition with the measurement at the end of test. Heijerick et al. (2003) demonstrated that chronic $\mathrm{Zn}$ toxicity in $\mathrm{D}$. magna is dependent on $\mathrm{pH}$, hardness and DOC concentration of the test medium. Nevertheless, DOC seems to be the most important toxicity factor capable of modifying and reducing $\mathrm{Zn}$ toxicity. Therefore, according to the parameters measured, it is possible to conclude that the effect of toxicity is essentially the outcome of exposed metal or molecular size. Table 3 registers the results of the metal effects upon reproduction and mortality (Fig. 2). For reproduction parameter, the toxicity effect was only observed when there was a concentration level of $20 \mu \mathrm{g} \mathrm{L}{ }^{-1}$ of As. However, there was a decrease of reproduction in the case of cobalt concentration of (50 and $100 \mu \mathrm{g} \mathrm{L}^{-1}$ ). Significant effects related to mortality were registered only in higher concentration of Co $\left(100 \mu \mathrm{g} \mathrm{L}^{-1} \mathrm{p}<0.05\right.$; Fig. 2D). Levels of concentration that were assessed reported no toxic effect related to mortality in neither of these 2 cases of As (Fig. 2A and B). Values of arsenic LC50 in freshwater reported in literature were in the range of $0.4 \mathrm{mg} \mathrm{L}^{-1}$ and $3 \mathrm{mg} \mathrm{L}^{-1}$. (Norwood et al., 2007; Wang et al., 2011; Liber et al., 2011). The results obtained in the present work are in accordance with values reported in literature. For cobalt, the authors reported a range of $5.1 \mu \mathrm{g}$ of Co L ${ }^{-1}$ to $4500 \mu \mathrm{g}$ of Co $\mathrm{L}^{-1}$ of toxicity for different organisms (De Schamphelaere et al., 2008; Marr et al., 1998; Diamond et al., 1992). The toxicity results showed that a low concentration of Co $\left(50 \mu \mathrm{L} \mathrm{L}^{-1}\right)$ can cause toxic effect for $C$. dubia, an effect confirmed through values referred to in literature.

\subsubsection{Molecular size effect}

ANOVA and deviation analyses, obtained by reproduction and mortality data, respectively, are reported in the Table 3 . The results indicated significant difference in the mean data of reproduction and mortality between the two type of treatments (different molecular size) and different metal concentration (As 10, As 20, Co 50 and Co 100: $\mathrm{p}<$ $0.05)$. However, there were not any difference in the case where metals were absent $(p>0.05)$. This result attests that the humic substance not affected negatively the results produced by AHS fractions and the effect observed were induced by metal or metal-AHS interactions. For mortality, effects of treatments were registered (molecular sizes) only for cobalt addition. No effect was observed above molecular size and biological variable in metal absence. Therefore, the results indicate the 


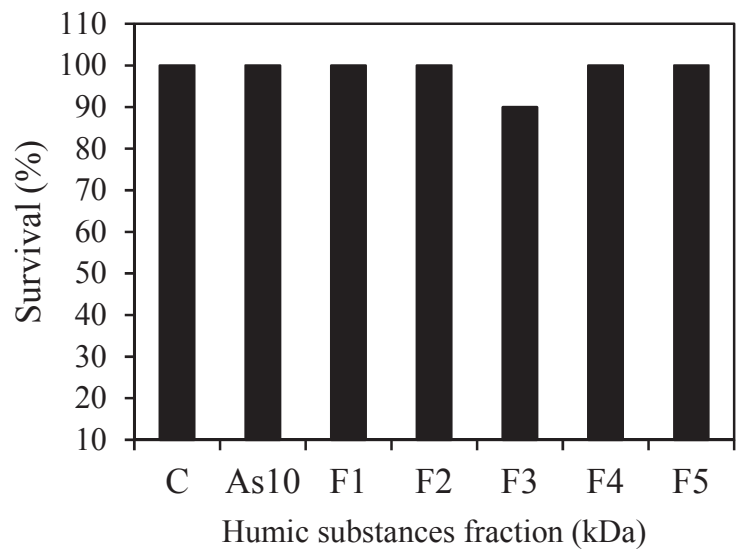

A

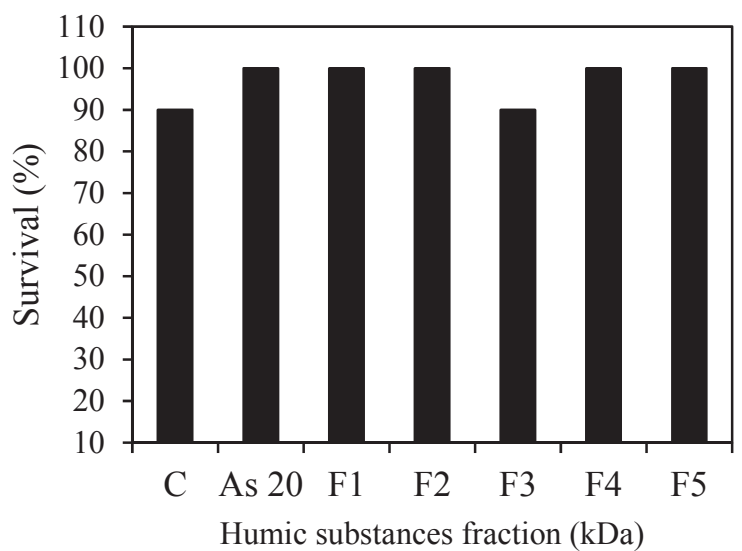

$\mathrm{B}$

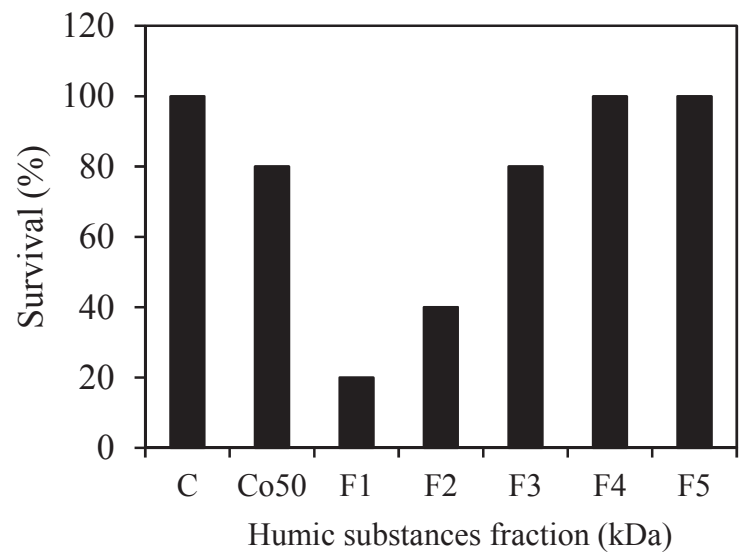

$\mathrm{C}$

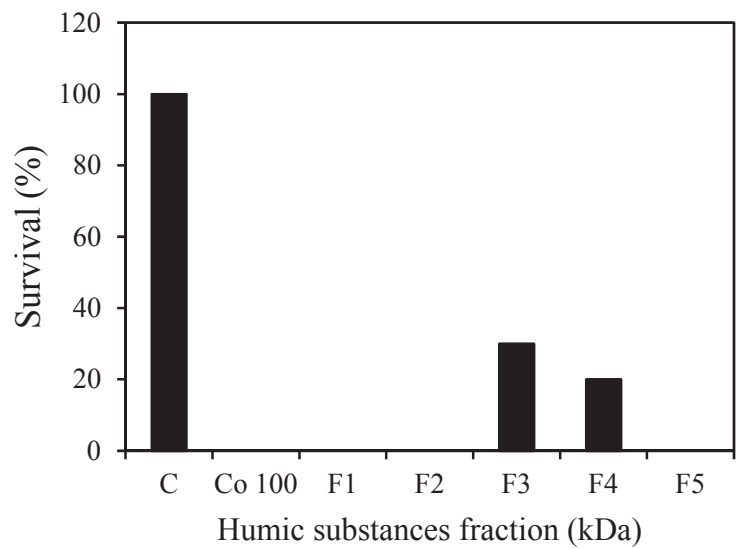

$\mathrm{D}$

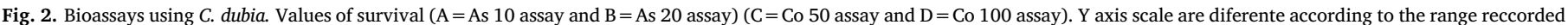

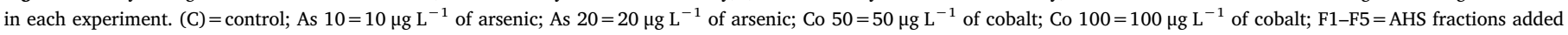
corresponding concentration solution.

effect of molecular size on reproduction and mortality only in presence of dopant.

The results obtained by statistical analyses using Turkey's test on reproduction data, showed the behavior in each experimental condition tested (Fig. 3). For As 10 (Fig. 3A), this variation occurred only in the fraction 2 (between 30 and $100 \mathrm{kDa}$ ). An improvement in reproduction when considering higher molecular size was observed in As 20. The opposite occurred comparing As 20 with Co 50 (Fig. 3C), where it is possible to observe the decrease in reproduction rate in case of bigger molecules. As it is shown in Fig. 3D, the higher concentration of cobalt showed elevated variation in reproduction values. Aught, we observed a negative effect with the presence of AHS in different molecular sizes, except in fraction 2. Burba et al. (1998) reported that transport, deposition and processes of humic substances can be influenced considerably by molecular size distribution in aquatic environments. According to the same study, literature informs that a great part of trace metals in natural waters fractionated by UF in the range from $0.45 \mathrm{~mm}$ to $1 \mathrm{kDa}$ were found to be associated preferably with aquatic humic macromolecules. Heavy metals were predominantly bound to highmolecular-mass colloids bigger than $10 \mathrm{kDa}$ (Burba et al., 1998). Oliveira et al. (2015) states that environmental anionic or neutral species and more than one mechanisms can contribute to formation of As(III)-AHS complexes. The same authors, after studying AHS enriched with $\mathrm{Fe}$ and $\mathrm{Al}$ by fluorescence spectra, observed changes in structures of fulvic and humic acids. The results demonstrated that the amount of organic matter and the chemical composition of the medium influence the bioavailability of arsenic in aquatic systems.

\subsection{Complexation experiments}

The complexed metal values in the AHS fractions of a concentration of $10 \mu \mathrm{g} \mathrm{L}{ }^{-1}$ and $20 \mu \mathrm{g} \mathrm{L}^{-1}$ and the complexed metal values in the fractions of AHS cobalt concentration of $50 \mu \mathrm{g} \mathrm{L}^{-1}$ are shown in Fig. 4. According to experimental data obtained, there was a low retention of arsenic by AHS over all the fractions. When complexation values were compared to toxicity values, it was not possible to establish the relationship between the two parameters, considering difference of molecular sizes. While experimental results showed a lower complexation capacity, the reproduction values showed the toxicity reduction in the presence of NOM in different fractions (i.e. F2 in the $10 \mu \mathrm{g} \mathrm{L}^{-1} \mathrm{As}$ ). Gontijo et al. (2016) studied the bioavailability of arsenic in Brazilian rivers, showing that a considerable part of As was inserted in the labile fraction, and can therefore be attributed to its bioavailability. In the same way, studies proposed by Oliveira et al. (2015) reported no interaction between $\mathrm{HS}$ and As (III) in natura or enriched with aluminum, taking into account NOM environmental relevant. Jones and Huang (2003) showed an apparent non-linear toxicity response for organic pesticides composed of arsenic after interacting with humic substances at varying concentrations, suggesting a complex relationship where several mechanisms for toxicity reduction may be operative. During the testing process, $\mathrm{KNO}_{3}$ and $\mathrm{MgHSO}_{4}$ salts were added according to the initial hardness value of the water according to standard procedure for water hardness adjust followed (US EPA, 2002; ABNT, 2010).

The complexed metal values of the AHS fractions in the concentration of $50 \mu \mathrm{g} \mathrm{L}^{-1}$ are shown in Fig. 4. By observing the free and total 


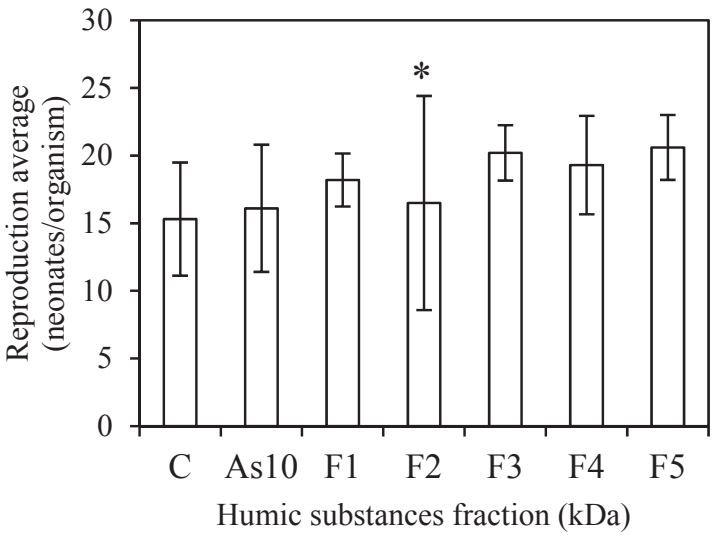

A

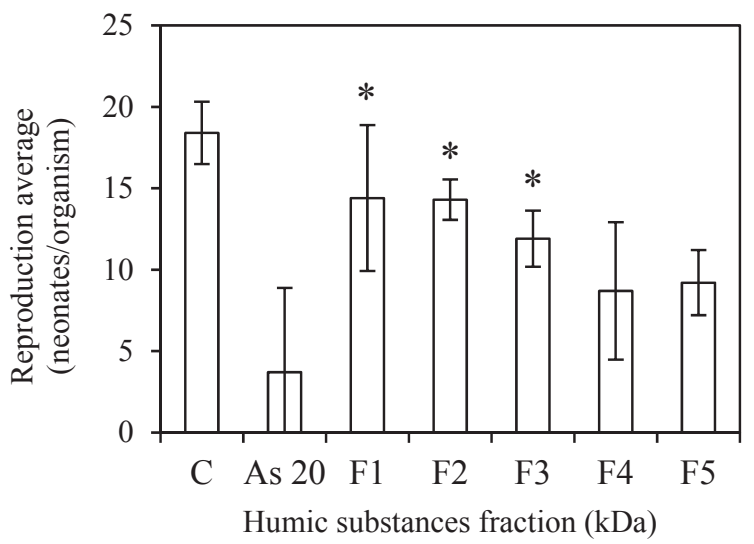

$\mathrm{B}$

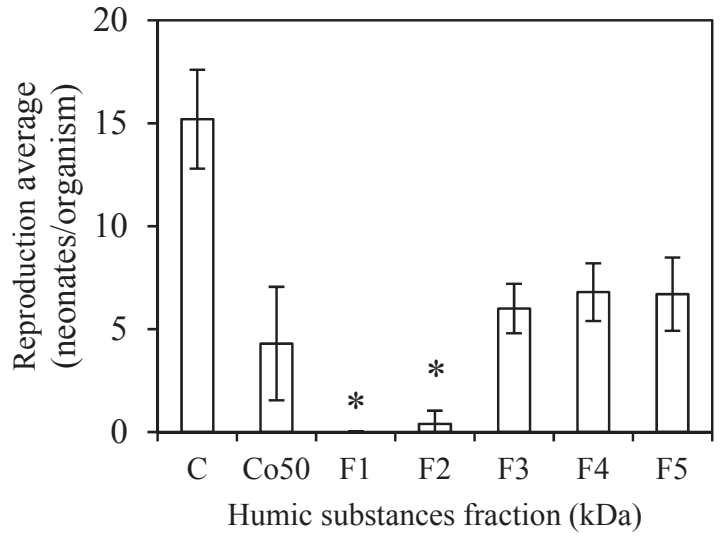

$\mathrm{C}$

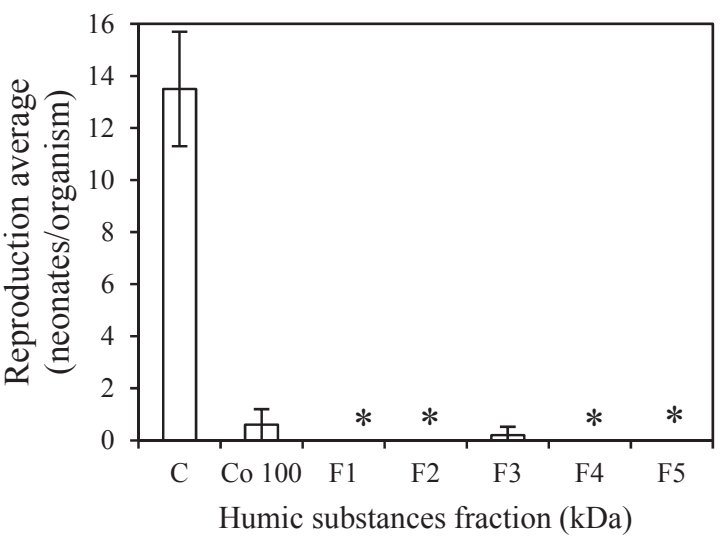

D

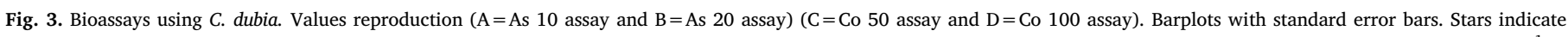

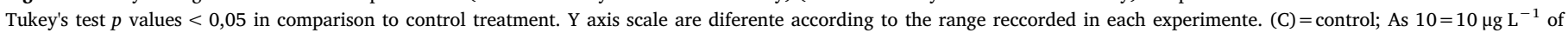
arsenic; As $20=20 \mu \mathrm{g} \mathrm{L}^{-1}$ of arsenic; Co $50=50 \mu \mathrm{g} \mathrm{L}{ }^{-1}$ of cobalt; Co $100=100 \mu \mathrm{g} \mathrm{L}^{-1}$ of cobalt; F1-F5=AHS fractions added corresponding concentration solution.

metal values, we concluded that there was a greater complexation of cobalt in fractions of lower molecular size F4 and F5. Despite the nonreduction of toxicity in these fractions, the raw values of neonates produced using these fractions were higher, when compared to their larger molecular size. Thus, it was possible to observe a relationship between the metal complexing toxicity levels and AHS fractionation. The cobalt ions retention in various concentrations was not accompanied by reduction in toxic effects, which may be related to the exchange of constant as described by Rocha and Rosa (2003). The value of the exchange constant $(\mathrm{kt})$ was found to be inversely proportional to the stability of the Co-AHS complexes. According to the exchange constant value determined for cobalt metal, the variations observed in the different fractions contained were: KtF4 $>>\mathrm{KtF} 1>\mathrm{KtF} 2>\mathrm{KtF} 3$. The high value of kt for F4 was compared to other fractions, which in turn showed the low stability of the Co-AHS complex. According to Pinheiro et al. (1999), the metal complexes resulting from the dissociation solution became more available, and hence more toxic. Thus, the low stability of the complex causes dissociation and an increased toxicity of the metal ions. One point that can be considered is about photo alteration during the experiments. The experimental condition (Table 1) showed a considerable photoperiod during the toxicological experiments. Literature data demonstrated that the photo alteration (radiance) indicating loss of aromatic character and intramolecular interactions, decrease in molecular weight and aggregation. In the same study it can be observed that high radiance results in the release of $\mathrm{Cu}, \mathrm{Cd}$ and $\mathrm{Pb}$ from complexes and an increase of intracellular concentration (Worms et al., 2015). The high complexation capacity of $\mathrm{Fe}$ and $\mathrm{Al}$ cations could also be used to justify the same principle and its related effect. AHS-Fe and Al-AHS complexes are considered stable and found to be less dependent on relative molecular size due to their low values of kt, when the fractions were observed (Rocha and Rosa, 2003). The concentration of humic substances was high enough to remove more than $90 \%$ of cobalt in case of $\mathrm{pH} 6$. Because humic acid is a natural material, the ultrafiltration of humic acid is considered an economically and environmentally feasible process to remove cobalt (Kim et al., 2005).

\section{Conclusions}

To conclude, the ecotoxicological assays using C. dubia based on different fractions of humic substances showed different behaviors of the depending substance. In case of arsenic, there was a noticeable reduction of toxicity levels in larger molecular size fractions which made it possible to observe the decrease in reproduction for smaller molecular sizes. However, in case of cobalt, its non-reducing toxicity effect was observed as well as its influence on molecular size of AHS. By taking into account these experimental effects on the reproduction and death of the organisms, it was observed that AHS fraction with a higher molecular size led to a notable mortality rate of almost $100 \%$ and for lower concentration an increase of reproduction rate for molecular size contrary to arsenic behavior.

Moreover, based on the experimental data of AHS complexation, it was possible to observe different relationships between its natural availability and toxic effects. We conclude that better understanding of the above mentioned interaction between a complex matrix such as AHS and its effects on aquatic environment is certainly promising and could lead to further more studies based on the mechanisms involved. 


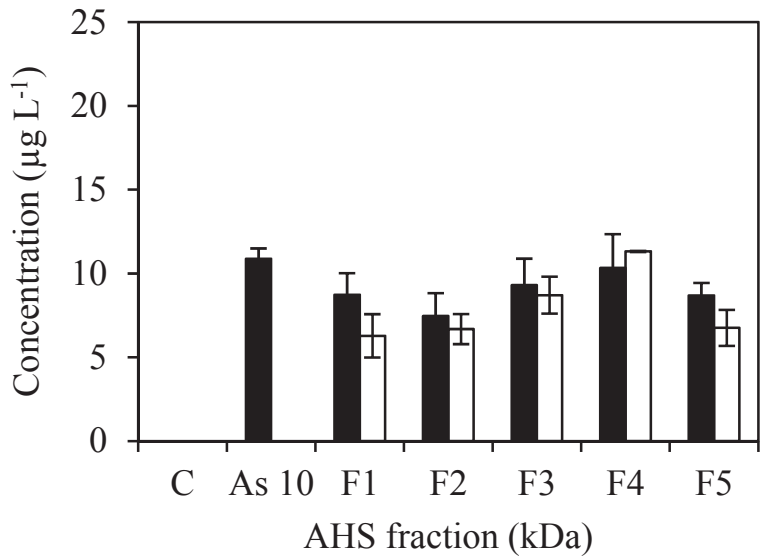

(a)

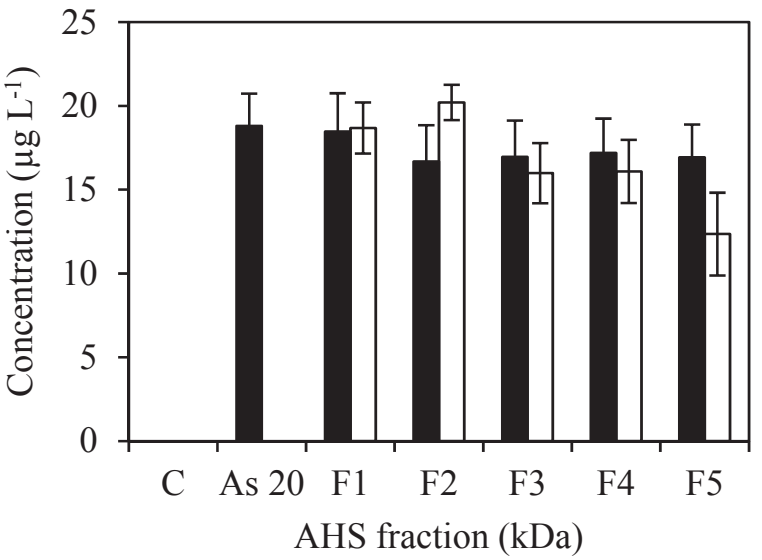

(b)

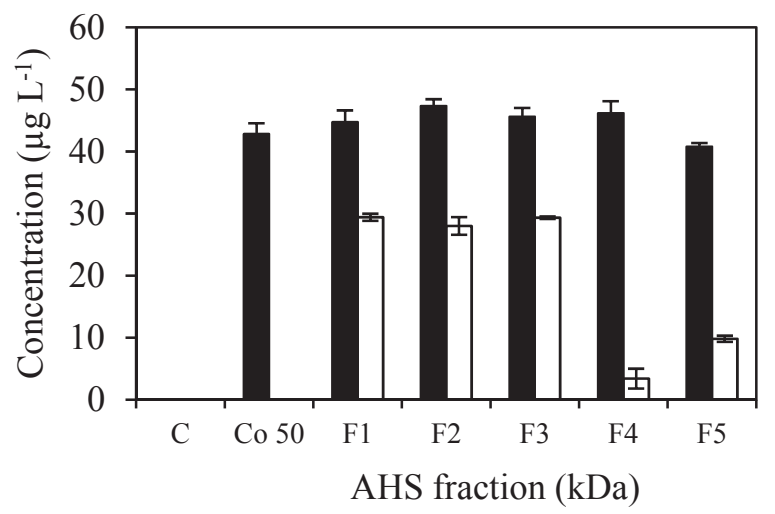

(T)

(F)

(c)

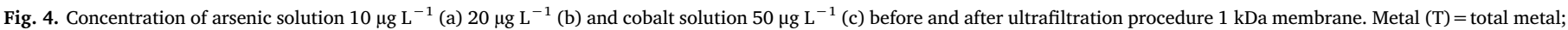

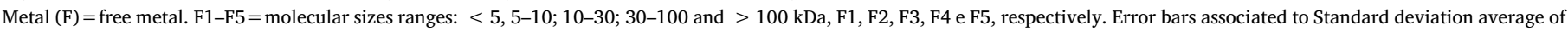
three measures.

\section{Acknowledgements}

We thank the following funding agencies of the Brazilian government for providing us with the necessary funding for our R \& D project at UNESP, Sorocaba, SP, Brazil. Foundation for Research of the State of São Paulo (FAPESP) proc. 2012/19580-4, proc. 2014/20979-4 proc. 2013/24168-8 and proc. 2016/08215-4, Coordination for the Improvement of Higher Education Personnel (CAPES) and National Research and Development Council (CNPq).

\section{Appendix A. Supplementary material}

Supplementary material associated with this article can be found in the online version at doi:10.1016/j.ecoenv.2017.01.018.

\section{References}

ABNT (Associação Brasileira de Normas Técnicas), 2010. NBR 13373:2010: Ecotoxicologia aquática, toxicidade crônica, método de ensaio com Ceriodaphnia spp (Crustacea, Cladocera). Rio de Janeiro.

Al-Reasi, H.A., Wood, C.M., Smith, D.S., 2011. Physicochemical and spectroscopic properties of natural organic matter (NOM) from various sources and implications for ameliorative effects on metal toxicity to aquatic biota. Aquat. Toxicol. 103 (3-4), 179-190.

Araújo, A.B., Rosa, A.H., Rocha, J.C., 2002. Metal distribution and characterization of exchange constants between metal species and aquatic humic fractions with different molecular sizes. Quím. Nova 25, 1103-1107.

Burba, P., Aster, B., Nifant'eva, T., Shkinev, V., Spivakov, B.Y., 1998. Membrane filtration studies of aquatic humic substances and their metal species: a concise overview Part 1. Analytical fractionation by means of sequential-stage ultrafiltration. Talanta 45 977-988.

Brasil, 2005. Classificação de águas, doces, salobras e salinas do Território Nacional. Resolução CONAMA no. 357, de 17 de março de.

R Core Team, 2016. R: A language and environment for statistical computing. R Foundation for Statistical Computing, Vienna, Austria.

Costa, C.R., Olivi, P., Botta, Clarice M.R., Espindola, E.L.G., 2008. Toxicity in aquatic environments: discussion and evaluation methods. Quim. Nova 31 (7), 1820-1830.

Craig, P., 1986. Organometallic compounds in the environment: principles and reactions. Uk: Willey, 368.

De Schamphelaere, K.A.C.D., et al., 2008. Reduction of growth and haemolymph Ca levels in the freshwater snail Lymnaea stagnalis chronically exposed to cobalt. Ecotoxicol. Environ. Saf. 71, 65-70.

Diamond, J.M., Winchester, E.L., Mackler, D.G., Rasnake, W.J., Fanelli, J.K., Gruber, D., 1992. Toxicity of cobalt to freshwater indicator species as a function of water hardness. Aquat. Toxicol. 22, 163-180.

Dodds, W.K., 2002. Freshwater Ecology: Concepts and Environmental Applications 1st ed.. Academic Press.

Gontijo, E.S.J., Watanabe, C.H., Monteiro, A.S.C., Tonello, P.S., da Silva, G.A., Friese, K., Roeser, H.M.P., Rosa, A.H., 2016. Distribution and bioavailability of arsenic in natural waters of a mining área studied by ultrafiltration and diffusive gradientes in thin films. Chemosphere 164 (9), 290-298.

Heijerick, D.G., Janssen, C.R., De Coen, W.M., 2003. The combined effects of hardness, $\mathrm{pH}$, and dissolved organic carbon on the chronic toxicity of $\mathrm{Zn}$ to D. magna: development of a surface response model. Arch. Environ. Contam. Toxicol. 44, 210-217.

Jain, C.K., Ali, I., 2000. Arsenic: occurrence, toxicity and speciation techniques. Water Res. 34 (17), 4304-4312.

Jones, K.D., Huang, W.-H., 2003. Evaluation of toxicity of the pesticides, chlorpyrifos and arsenic, in the presence of compost humic substances in aqueous systems. J. Hazard. Mater. B103, 93-105.

Kim, H.-J., Baek, K., Kim, B.-K., Yang, J.-W., 2005. Humic substance-enhanced ultrafiltration for removal of cobalt. J. Hazard. Mater. A122 (6), 31-36. 
Liber, K., Doig, L.E., White-Sobey, S.I., 2011. Toxicity of uranium, molybdenum, nickel, and arsenic to Hyalella azteca and Chironomus dilutus in water-only and spiked. Ecotoxicol. Environ. Saf. 74, 1171-1179.

Lock, K., Becaus, S., Criel, P., Van Eeckhout, H., Janssen, C.R., 2004. Ecotoxicity of cobalt to the springtail Folsomia candida. Comp. Biochem. Physiol. Part C 139, 195-199.

Logan, M., 2010. Biostatistical Design and Analysis Using R: A Practical Guide. Wiley Blackwell, Oxford, UK, 577.

Markich, S.J., Warne, M.S., Westbury, A.-M., Roberts, C.J., 2002. A compilation of data on the toxicity of chemicals to species in Australasia. Part 3: metals. Aust. J. Ecotoxicol. 8, 1-7.

Marr, J.C.A., Hansen, J.A., Meyer, J.S., Cacela, D., Podrabsky, T., Linpton, J., Bergman, H.L., 1998. Toxicity of cobalt and copper to rainbow trout: application of a mechanistic model for predicting survival. Aquat. Toxicol. 43, 225-238.

Moruzzi, R.B., Reali, M.A.P., 2012. Iron and manganese oxidation and removal from public and industrial water - a general approach. Rev. Eng. Technol. 4 (1), 29-43.

Oliveira, L.K., Melo, C.A., Goveia, D., Lobo, F.A., Hernández, M.A.A., Fraceto, L.F., Rosa, A.H., 2014. Adsorption/desorption of arsenic by tropical peat: influence of organic matter, iron and aluminium. Environ. Technol., 12.

Oliveira, L.K., Melo, C.A., Fraceto, L.F., Friese, K., Rosa, A.H., 2015. Interaction of arsenic species with tropical river aquatic humic substances enriched with aluminum and iron. Environ. Sci. Pollut. Res. 12. http://dx.doi.org/10.1007/s11356-015-5816-5.

Pinheiro, J.P., Mota, A.M., Van Leeuwen, H.P., 1999. On lability of chemically heterogeneous systems-complexes between trace metals and humic matter. Colloid Surf. A: Physicochem. Eng. Asp. 151, 181-187.

Nifant'eva, T.I., Shkinev, V.M., Spivakov, B.Y., Burba, P., 1999. Membrane filtration studies of aquatic humic substances and their metal species: a concise overview. Part 2. Evaluation of conditional stability constants by using ultrafiltration. Talanta 48, 257-267.

Norwood, W.P., Borgmann, U., Dixon, D.G., 2007. Chronic toxicity of arsenic, cobalt, chromium and manganese to Hyalella azteca in relation to exposure and bioaccumulation. Environ. Pollut. 147, 262-272.

Rocha, J.C., Zara, L.F., Rosa, A.H., Sargentini Junior, É., Burba, P., 2000. Substâncias húmicas: sistema de fracionamento sequencial por ultrafiltração com base no tamanho molecular. Química Nova 23 (3), 410-412.

Rocha, J.C., Rosa, A.H., 2003. Substâncias húmicas aquáticas: interações com espécies metálicas. Editora UNESP, São Paulo.

Rocha, J.C., Rosa, A.H., Cardoso, A.A., 2004. Introdução à Química Ambiental. Bookman, Porto Alegre.

Rosa, A.H., Simões, M.L., Oliveira, L.C., Rocha, J.C., Martin Neto, L.M., Milori, D.M.B.P., 2005. Multimethod study of degree of humification of humic substances extracted from different tropical soil profiles in Brazil's Amazonian region. Geoderma 127, $1-10$.

Santos, A.C., et al., 2011. Characterization of interactions between natural organic matter and metals by tangential-flow ultrafiltration and ICP OES. J. Braz. Chem. Soc. Camp., 98-103.

Sargentini, É., Jr., et al., 2001. Substâncias húmicas aquáticas: fracionamento molecular e caracterização de rearranjos internos após complexação com íons metálicos. Quim. Nova 24 (3), 339-344.

Siegel, F.R., 2002. Environmental Geochemistry of Potentially Toxic Metals. Springer, Berlin; Heidelberg; New York; Barcelona; Hongkong; London; Mailand; Paris; Tokio.

Simonsen, L.O., Harbak, H., Bennekou, P., 2012. Cobalt Metabolism and Toxicology: A Brief Update. Departamento de Biologia, Universidade de Copenhagen, Copenhagen.

Stevenson, F.J., 1994. Humus Chemistry: Genesis, Composition and Reaction. John Wiley \& Sons, New York.

I. H. Suffet, P. MacCarthy (Eds.), Aquatic Humic Substances: Influence of Fate and Treatment of Pollutants, Advances in Chemistry Series 2191989 American Chemical Society Washington, DC.

Swift, R.S., 1989. Molecular weight, size, shape and charge characteristics of humic substances: some basic considerations. In: Hayes, M.H.B. (Ed.), Humic Substances II. John Wiley \& Sons, New York.

Thurman, E.M., Malcolm, R.L., 1981. Preparative isolation of aquatic humic substances. Environ. Sci. Technol. 15 (4), 463-466.

US EPA, 2002. United States Environmental Protection Agency. Short-term methods for estimating the chronic toxicity of effluents and receiving water to freshwater organisms. 4th ed. Washington D.C. p. 266.

US EPA, 1996. United States Environmental Protection Agency. METHOD 3050B: Acid Digestion of Sediments, Sludges, and Soils. 2nd ed. Washington D.C. p. 12. Disponível em: 〈www.epa.gov/osw/hazard/testmethods/sw846/pdfs/3050b.pdf〉 (acesso em: 31.07.15).

Walker, C.H., Sibly, R.M., Hopkin, S.P., Peakall, D.B., 2012. Principles of Ecotoxicology 4th ed.. CRC Press, EUA.

Wang, D., Forthaus, J.H.B.E., Wang, J., 2011. Synergistic toxic effect of nano-Al2O3 and As(V) on Ceriodaphnia dubia. Environ. Pollut. 159, 3003-3008.

Wetzel, R.G., 2001. Limnology: Lake and Rivers Ecossystems 3rd ed.. Academic Press, EUA.

Worms, I.A.M., Adenmatten, D., Miéville, P., Traber, J., Slaveykova, V.I., 2015. Phototransformation of pedogenic humic acid and consequences for $\mathrm{Cd}(\mathrm{II}), \mathrm{Cu}(\mathrm{II})$ and $\mathrm{Pb}$ (II) speciation and bioavailability to green microalga. Chemosphere 138 (8), 908-915. 